\title{
In vitro and in vivo control of yam dry rot nematodes using pyroligneous extracts from palm trees ${ }^{1}$
}

\author{
Sara Padilha de Farias ${ }^{2}$, Alison Van Der Linden de Almeida ${ }^{2}$, Everton Sebastião do Nascimento ${ }^{2}$, \\ João Inácio Soletti ${ }^{3}$,Tatiane Luciano Balliano ${ }^{3}$, Gilson Moura Filho ${ }^{2}$, Maria de Fatima Silva Muniz ${ }^{2 *} \mathbb{D}$ \\ 10.1590/0034-737X202067060008
}

\begin{abstract}
Dry rot of yam (Dioscorea spp.) caused by Scutellonema bradys and Pratylenchus spp. has restricted yam production in Brazil. Plant-based products can be useful reducing nematode damages. The objectives of this study were to evaluate the nematostatic and nematicidal in vitro activities of pyroligneous extracts from Cocos nucifera, Syagrus cearensis, $S$. coronata, and Wodetia bifurcata palms against $S$. bradys and to evaluate the effect of $C$. nucifera pyroligneous extract in the treatment of yam tubers infected by S. bradys and Pratylenchus sp. under greenhouse conditions. The pyroligneous extracts obtained at pyrolysis temperatures of $400,500,600$, and $700{ }^{\circ} \mathrm{C}$, and at different concentrations, were tested for nematode immobility and mortality in Kline slides. Cocos nucifera pyroligneous extract obtained at $400{ }^{\circ} \mathrm{C}$ and $1 \%$ concentration was tested on yam tubers, under different immersion periods. Six months after yam planting the nematode populations were evaluated. All pyroligneous extracts inhibited the mobility and caused mortality to S. bradys, however 100\% inhibition of both variables was achieved at concentrations varying from 0.75 to $2 \%$, depending on the pyrolysis temperatures. The reproduction factor was reduced in $43 \%$ by treating infected yam tubers with pyroligneous extract from C. nucifera.
\end{abstract}

Keywords: alternative control; Arecaceae; Dioscorea spp.; Scutellonema bradys; Pratylenchus sp.

\section{INTRODUCTION}

Yam (Dioscorea spp.) production in Brazil has been affected by many factors; among these, the well-known dry rot disease, which is caused by the plant-parasitic nematodes Scutellonema bradys (Steiner \& LeHew) Andrássy, Pratylenchus coffeae (Zimmermann) Filipjev $\&$ Schuurmans Stekhoven and P. brachyurus (Godfrey) Filipjev \& Schuurmans Stekhoven. The incidence of these nematodes produces symptoms of necrosis in the outer parenchymatous tissues of yam tubers, resulting in decreased productivity and depreciating the product quality (Moura, 2016).

The most effective managing technique for the dry rot disease relies in the use of nematode-free seeds. However, this practice has little feasibility due the difficulty to obtain healthy planting material (Moura, 2016). In Brazil, there are no nematicides registered for yams (Agrofit, 2020). Several authors have searched for new alternatives to control the disease, including the use of plant extracts (Coimbra et al., 2006; Lima et al., 2019).

A new strategy to obtain plant compounds with biopesticide potential arises by a thermo-chemical process, known as pyrolysis, which is performed in the absence of oxygen to convert biomass in liquid, solid, and gases (Shaw, 2006). The liquid fraction, also known as pyroligneous acid, wood vinegar, pyroligneous liquor, liquid smoke, and bio-oil, has several applications in agriculture (Campos, 2007). The liquid product is formed by one aqueous phase (pyroligneous extracts), and other organic phase known as bio-oil ( Basu, 2010; Bridgwater, 2012).

Some authors pointed out the use of pyroligneous extracts of plant biomass as a promising source to control

\footnotetext{
Submitted on May 22 th, 2020 and accepted on August $19^{\text {th }}, 2020$

${ }^{1}$ This work is part is part of the first author's Doctoral Thesis.

${ }^{2}$ Universidade Federal de Alagoas, Centro de Ciências Agrárias, Rio Largo, Alagoas, Brazil. sarapadilha.farias@outlook.com; alisonvander11@hotmail.com; evertohn@ @otmail.com; gmf.ufal@yahoo.com.br; mf.muniz@uol.com.br

${ }_{3}^{3}$ Universidade Federal de Alagoas, Departamento de Engenharia Química, Maceió, Alagoas, Brazil. jisoletti@gmail.com; tlb@qui.ufal.br

"Corresponding author: mf.muniz@uol.com.br
}

Rev. Ceres, Viçosa, v. 67, n.6, p. 482-490, nov/dec, 2020 
plant pests and diseases (Azevedo et al., 2013; Trindade et al., 2014; Pieta, 2017), including plant-parasitic nematodes (Corbani, 2008; Santos et al., 2017). The antimicrobial activity of pyroligneous extracts is attributed to the presence of phenolic compounds, carbonyls and organic acids (Campos, 2018). Some species of Arecaceae commonly found in Brazil and not yet known in relation to their biological activity on plant pathogens have showed antimicrobial effects on human pathogens, for instance, ouricuri [(Syagrus coronata (Mart.) Becc.)] (Hughes et al., 2013; Bessa et al., 2016), and coconut (Cocos nucifera L.) (Igwe \& Ugwunnaji, 2016). Studies related to the biological potential of pyroligneous extracts obtained from palm trees regarding plant pathogens, should be performed.

The objectives of this study were: $i$ ) to test the nematostatic and nematicidal effects of pyroligneous extracts from coconut, catolé (Syagrus cearensis Noblick), ouricuri and foxtail palms (Wodetia bifurcata Irvine) against the yam nematode $S$. bradys in vitro, and ii) to evaluate the effect of coconut pyroligneous extract in the treatment of yam tubers naturally infected by $S$. bradys and Pratylenchus sp. under greenhouse conditions.

\section{MATERIALAND METHODS}

\section{Experimental site}

The experiments were performed at the Laboratory of Plant Pathology and greenhouse of the Research Center for Agricultural Sciences, Federal University of Alagoas (UFAL), Rio Largo, AL, Brazil.

\section{Pyroligneous extracts origin}

The pyroligneous extracts were obtained at the Chemical Department from the Federal University of Alagoas, Brazil. All extracts were obtained from the fruit endocarp (agro-industrial waste) of the palm species and under different pyrolysis temperatures from 400 to $700^{\circ} \mathrm{C}$, heating rate of $10^{\circ} \mathrm{C} \mathrm{min}-{ }^{1}$ and residence time of 2 hours (Vieira, 2019).

\section{In vitro assays of the pyroligneous extracts on Scutellonema bradys}

Yam tubers (Dioscorea cayenensis Lam.) exhibiting typical dry rot symptoms were collected in the field, in the state of Alagoas, Brazil, and then the nematodes were extracted according to the method of Coolen \& D'Herde (1972). Nematode identification was based on their morphological characteristics according to Mai \& Mullin (1996).

The pyroligneous extracts from $C$. nucifera, $S$. cearenses, $S$. coronata, and W. bifurcata, obtained at four different pyrolysis temperatures $(400,500,600$, and 700 ${ }^{\circ} \mathrm{C}$ ), were diluted in water at concentrations of $0,0.25,0.50$, $0.75,1.0$, and $2.0 \%$. In Kline plates $200 \mu \mathrm{L}$ of each extract and for each concentration were added before individually transferring 20 nematodes (juveniles and adults) from the extraction suspension to each cavity with the aid of a fine insect pin. Subsequently, plates were placed in plastic boxes containing filter paper soaked in distilled water, in order to maintain the humidity, and kept at room temperature. After $24 \mathrm{~h}$ of incubation the nematode specimens remaining motionless were counted under an inverted light microscope and transferred to distilled water; those which did not recover motility after 24 hours were considered as dead.

Four assays were performed to test each extract in a completely randomized design in factorial scheme (4 pyrolysis temperatures x 6 extract concentrations) with four replicates. The data were analyzed by analysis of variance using the statistical software SAEG 9.1, and response surface graphics were generated using the software Statistics 12.0.

\section{In vivo assay of the pyroligneous extracts of coconut on Scutellonema bradys and Pratylenchus sp.}

Under greenhouse conditions, yam tuber seeds $(D$. cayenensis) with symptoms of dry rot disease were collected from yam production areas in the state of Alagoas. Only the pyroligneous extract obtained at a pyrolysis temperature of $400{ }^{\circ} \mathrm{C}$ from the fruit endocarp of C. nucifera was tested, due to the better nematostatic and/or nematicidal effect demonstrated in vitro, and due to the availability of the material. Samples of $1 \mathrm{~g}$ of each tuber peel were processed according to Coolen \& D'Herde (1972) method, to determine the initial population (Pi). Nematode quantification was performed in Peters slides, under an inverted light microscope.

Sprouting yam seed tubers were immersed for 2, 3, 4, and 5 hours, based on a preliminary test. Subsequently, the tubers were planted in plastic pots, with $8 \mathrm{~kg}$ capacity, containing sterilized soil. Six months after planting, roots and tubers were collected to determine the roots and tuber peel fresh weight. After weighing, the nematodes were extracted according to Coolen \& D'Herde (1972) method, while $100 \mathrm{~cm}^{3}$ of soil were processed according to Jenkins (1964). The total number of nematodes was divided by the root or tuber peel weight, to obtain the number of nematodes $\mathrm{g}^{-1}$ tissue. The reproduction factor $(\mathrm{RF})$ of the nematodes $[\mathrm{RF}=$ Final population (roots + tubers + soil $) /$ Initial population from the tubers] was also calculated for each replicate. The experiment was performed under completely randomized design with four treatments plus the control, and eight replicates. Data were submitted to analyses of variance and, when statistically significant $(\mathrm{P}$ $\leq 0.05$ ), to regression analysis using the statistical software SAEG 9.1. 


\section{RESULTS}

\section{In vitro assays of the pyroligneous extracts on Scutellonema bradys}

Significance was observed for all the products tested concerning the percentage of S. bradys immobility (PIM) and mortality (PMORT), depending on the concentrations and the pyrolysis temperatures (Table 1). The exposition of the nematodes to pyroligneous extracts resulted on morphological alterations similar to vacuoles, which were observed in high numbers in all nematodes. No apparent variations were observed on the nematode body from control treatment (Figure 1).

There was a higher effect of PIM and PMORT when the concentrations increased for all pyroligneous extracts tested. Moreover, increasing concentrations resulted in a tendency to stabilize the nematostatic and nematicidal effects, which reached the maximum point (100\%) at a concentration between 0.75 and $2 \%$, depending on the pyrolysis temperatures (Figures 2 and 3 ).

Concerning the pyroligneous coconut extract, increasing concentration resulted in higher PIM, regardless the pyrolysis temperature (Figure 2A). As the regression effect was quadratic for concentration, the maximum value for nematode immobility was reached between 0.75 and $1.0 \%$, depending of the pyrolysis temperature. However, for temperatures between 400 and $600{ }^{\circ} \mathrm{C}$, the maximum was observed at a concentration of $0.75 \%$, and at $700{ }^{\circ} \mathrm{C}$ the maximum immobility was observed near the concentration of $1.0 \%$. Therefore, the pyrolysis temperature showed a negative linear effect on PIM, according to the adjusted model. Thus, higher temperatures caused a slight reduction in PIM, allowing to achieve a maximum value at higher concentrations. Furthermore, increasing the concentration of the pyroligneous extract from coconut correspondingly increased PMORT, independent of the pyrolysis temperature (Figure 2B). As the effect was quadratic for concentration, the maximum nematode mortality was reached between 0.75 and $1.0 \%$, depending on the pyrolysis temperature. For lowest temperatures (400 and $500{ }^{\circ} \mathrm{C}$ ) the maximum PMORT occurred at $0.75 \%$, and at higher temperatures $\left(600\right.$ and $\left.700^{\circ} \mathrm{C}\right)$, the maximum value was close to $1.0 \%$. In addition, the pyrolysis temperature showed a negative linear effect on PMORT, according to the adjusted model, showing the increase in temperature caused a slight reduction on PMORT, allowing to achieve a maximum value at higher concentrations.

In the case of foxtail palm, the PIM was also concentration-dependent, as PIM increased with an increase in the concentration of the pyroligneous extract, independent of the pyrolysis temperature (Figure 2C). As the effect was quadratic for concentration, the maximum

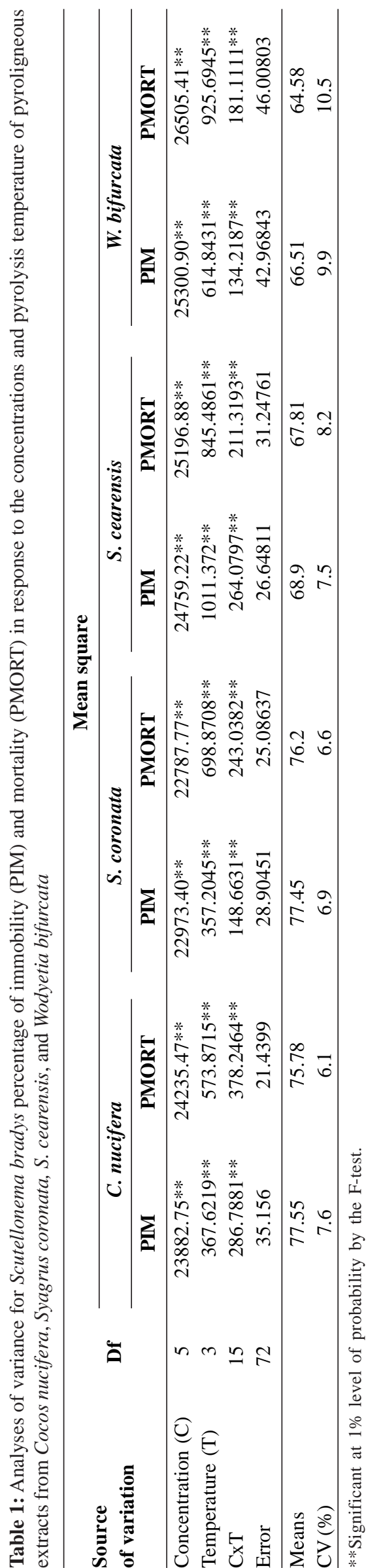


nematode immobility was reached at $1 \%$, for pyrolysis temperature between 400 and $600{ }^{\circ} \mathrm{C}$. At $700{ }^{\circ} \mathrm{C}$, the maximum PIM occurred at $0.75 \%$, due to the quadratic effect of the temperature, as a decrease of PIM occurred with the increase of temperature from 400 to $500{ }^{\circ} \mathrm{C}$, and an increase in PIM occurred between 600 and $700{ }^{\circ} \mathrm{C}$. Similar results were observed for PMORT (Figure 2D).

In catolé, the PIM was influenced by the extract concentration, and the maximum value was reached at $1.0 \%$, independent of the pyrolysis temperature (Figure 3A). The temperature showed a negative linear effect on PIM, according to the adjusted model, that is, the increase on the temperature triggered a slight decrease in PIM, however, did not interfere in the maximum concentration determined (1\%). Similar results were observed for PMORT (Figure 3B).

Concerning the pyroligneous extract from ouricuri, the increase of PIM was concentration-dependent, and independent of the pyrolysis temperatures (Figure 3C). As the effect was square root model for concentration, the maximum nematode immobility was reached near $1 \%$, for temperatures between 400 and $600{ }^{\circ} \mathrm{C}$. At $700{ }^{\circ} \mathrm{C}$, the concentration resulting in a maximum PIM fell to $0.75 \%$. This behavior was due to the effect of the model, that is to say, there was a decrease in PIM with the increase of the temperature between 400 and $500{ }^{\circ} \mathrm{C}$, and an increase in PIM between 600 and $700{ }^{\circ} \mathrm{C}$. Similar behavior was also observed for PMORT (Figure 3D).

\section{In vivo assay of the pyroligneous extracts of coconut on Scutellonema bradys and Pratylenchus sp.}

Only $S$. bradys was detected in the initial population, however, mixed population formed by $S$. bradys $(92.86 \%)$ and Pratylenchus sp. (7.13\%) was observed in the final population. This is likely due to the low population density of Pratylenchus sp. in the seed tubers, associated to the low weight $(1 \mathrm{~g})$ of the tuber skin used for extraction in the determination of the initial population of the nematodes. Among the analyzed variables, significant difference was
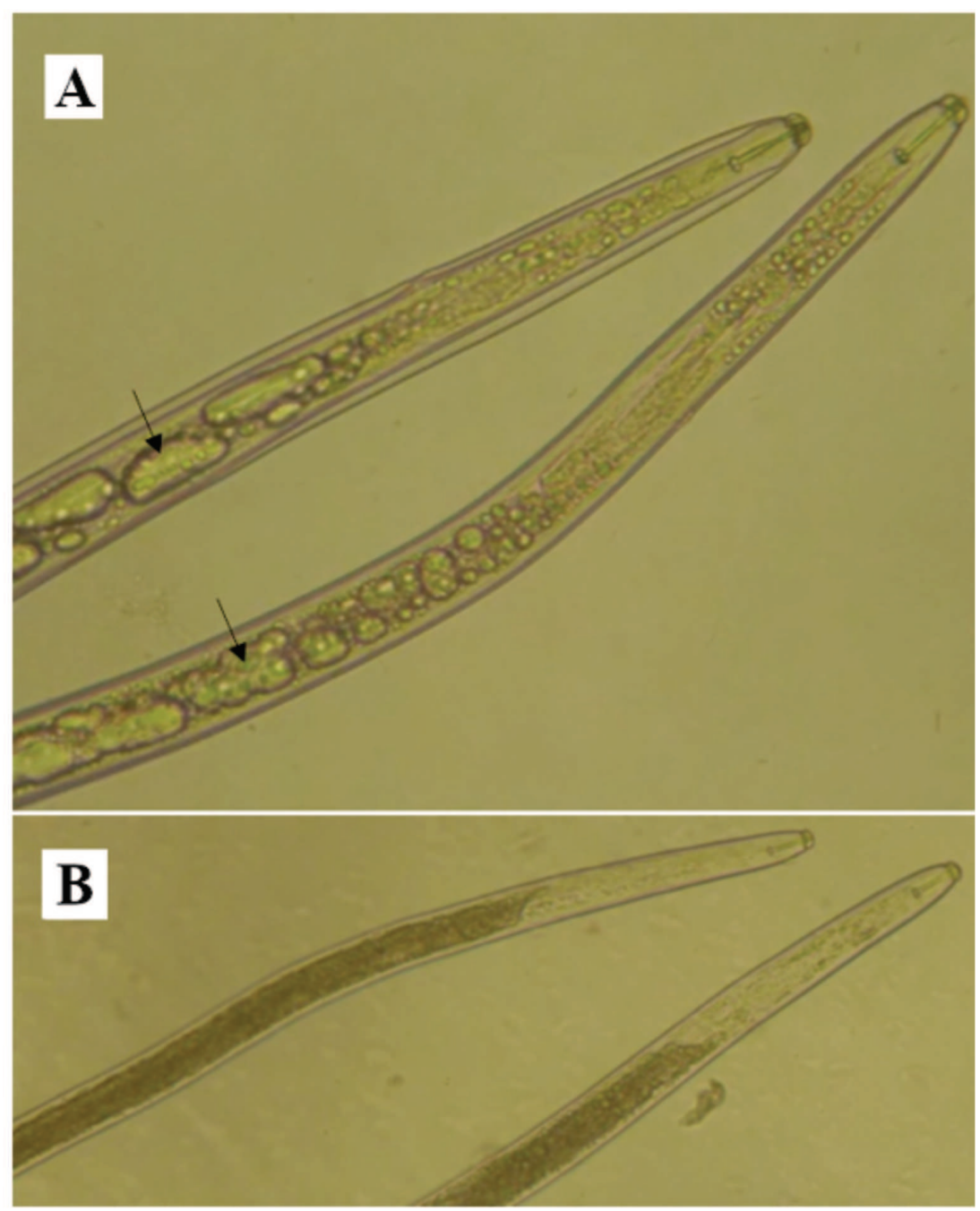

Figure 1: Characteristics observed within Scutellonema bradys bodies: A - after 24 hours of incubation in pyroligneous extracts, showing morphological changes similar to vacuolation (arrow) (200X magnification), B - control (100X magnification). 
observed only for the reproduction factor (RF), which was reduced by $43 \%$ from the immersion period of 5 hours when compared to the control. This variation can be represented by the linear model with the coefficient of determination $\left(\mathrm{R}^{2}\right)$ of 0.985 (Figure 4 ).

\section{DISCUSSION}

Results from the present study demonstrated that all pyroligneous extracts caused immobility and mortality to $S$. bradys, mostly independent of the pyrolysis temperatures. These results did not corroborate those published by Booker et al. (2010) who observed the activity of bio-oils from tobacco leaves (Nicotiana tabacum L.) ranged according to the pyrolysis temperatures, having a decreasing activity with the increase of temperature up to $550{ }^{\circ} \mathrm{C}$; and at $450{ }^{\circ} \mathrm{C}$, the greatest growth inhibition was observed for Streptomyces scabies (Thaxter) Waksman \& Henrici, Clavibacter michiganensis (Smith) Davis and Pythium ultimum Trow. According to these authors, this could be attributed to the active components being cracked into smaller, inactive components due to the increase of the temperature.

It is important to emphasize that the chemical nature of the liquid fraction, as well as the other components obtained from the pyrolysis process (solids and gases), depends on the feedstock and other variables as the temperature, residence time, and heating rates (Czernik \& Bridgwater, 2004; Mohan et al., 2006). For instance, cellulose degradation occurs at $240-350{ }^{\circ} \mathrm{C}$ to produce anhydrocellulose and levoglucosan; hemicellulose decomposes at temperatures of $200-260{ }^{\circ} \mathrm{C}$ and its degradation produces carboxylic acids; and lignin decomposes when heated at 280 to $500{ }^{\circ} \mathrm{C}$, and consists mainly of phenolic compounds (Mohan et al., 2006; Guedes et al., 2010). According to Campos (2018) the antimicrobial activity of pyroligneous extracts is due to the presence of phenolic compounds, carbonyls, and organic acids.

Pyroligneous extracts of coconut and ouricuri obtained at pyrolysis temperature of $400{ }^{\circ} \mathrm{C}$ and analyzed by gas
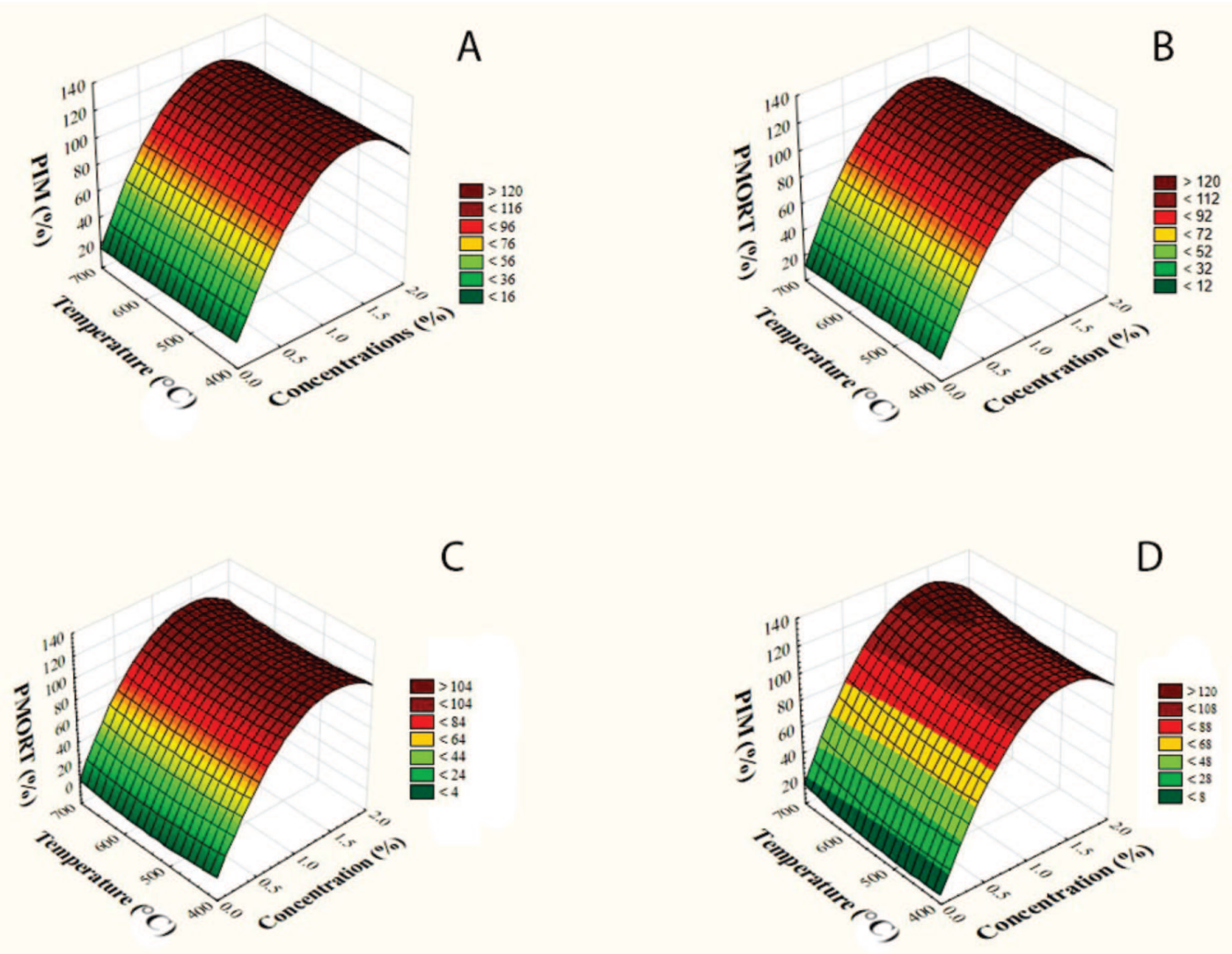

Figure 2: Response surface graphics for pyrolysis temperatures $\left(400,500,600\right.$, and $\left.700{ }^{\circ} \mathrm{C}\right)$, and pyroligneous extracts concentrations $(0,0.25,0.50,0.75,1.0$, and $2.0 \%)$ on percentage of immobility (PIM) and mortality (PMORT) in Scutellonema bradys. Coconut (a, b) and foxtail palm (c, d). Regression equations - PIM: Coconut $=25.87+155.1650 * \mathrm{C}-57.7616^{*} \mathrm{C} * \mathrm{C}-0.0148 * \mathrm{~T}\left(\mathrm{R}^{2}=0.849, \mathrm{P}\right.$ $<0.05)$; foxtail palm $=49.83+154.0530 * \mathrm{C}-53.2227 * \mathrm{C}^{\wedge} 2-0.1834 * \mathrm{~T}+0.0001924 * \mathrm{~T}^{\wedge} 2\left(\mathrm{R}^{2}=0.950, \mathrm{P}<0.05\right.$. PMORT: Coconut $=24.02+157.374 * \mathrm{C}-57.9692 * \mathrm{C} * \mathrm{C}-0.0173 * \mathrm{X}\left(\mathrm{R}^{2}=0.864, \mathrm{P}<0.05\right)$; foxtail palm $=61.20+155.3660 * \mathrm{C}-53.1017 * \mathrm{C}^{\wedge} 2-$ $0.2364 * \mathrm{~T}+0.000219 * \mathrm{~T}^{\wedge} 2\left(\mathrm{R}^{2}=0.950, \mathrm{P}<0.05\right) ; \mathrm{T}=$ temperature $; \mathrm{C}=$ concentration. 
chromatography coupled to mass spectrometry showed the following chemical groups: aldehyde, phenolic aldehyde, ketone, ether, phenol, hydrocarbons, and terpenes (coconut), and carboxylic acid, organic acid, aldehyde, phenolic aldehyde, ketone, ether, and phenol (ouricuri) (Vieira, 2019). Among these compounds the chemical groups of aldehydes, phenols, terpenes, or organic acids, are known as nematicidal substances against Bursaphelenchus xyloplilus (Steiner et Buhrer) Nickle, Panagrellus redivivus (L.) Goodey, Caenorhabditis elegans (Maupas) Dougherty (Li et al., 2009); Heterodera zeae Koshy, Swarup \& Sethi (Faizi et al., 2011); C. elegans (Abdel-Rahman et al., 2013) and Meloidogyne incognita Kofoid \& White (Aoudia et al., 2012; Caboni et al., 2013; Seo \& Kim, 2014).

The organic acids, acetic acid and lactic acid were tested alone and in combination, promoting $100 \%$ mortality of $M$. incognita second-stage juveniles at a concentration of $0.1 \%$ (acetic acid and mixtures) and $0.5 \%$ (lactic acid). Furthermore, the nematode bodies were disrupted severely and moderately by vacuolation at $0.5 \%$ mixed and single organic acids, respectively (Seo \& Kim, 2014). This suggests that probably, the nematostatic/nematicidal effect observed in the present study, was due to the occurrence of some organic acids present in the pyroligneous extracts, considering that vacuolation observed was similar to those previously described.

High predominance of phenolic compounds was also observed in bio-oils from coconut fibers (Almeida et al., 2013) and coconut shell (Gao et al., 2016; Hadanu \& Apituley, 2016) at pyrolysis temperatures varying from $350-700{ }^{\circ} \mathrm{C}$. Probably, the presence of these compounds in the pyroligneous extracts of coconut used in the present study contributed for their effect on S. bradys. However, the bio-activity of $C$. nucifera on nematodes is poorly documented. As example, the studies of coconut extracts against intestinal nematodes (Oliveira et al., 2009; Costa et al., 2010).

The RF decrease observed in the present study (3.6 to $2.04)$ is a valuable information for the management of these
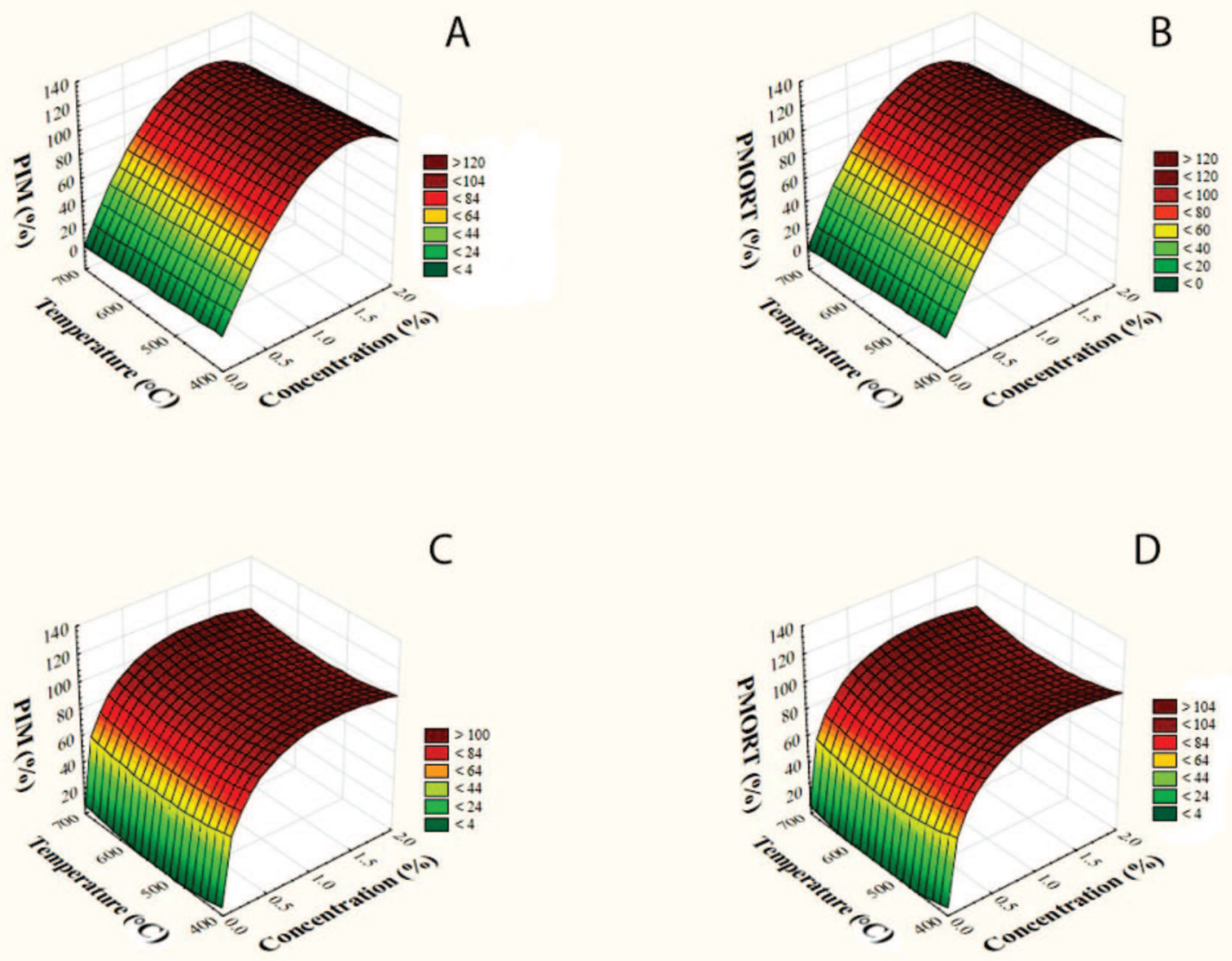

Figure 3: Response surface graphics for pyrolysis temperatures $\left(400,500,600\right.$, and $\left.700{ }^{\circ} \mathrm{C}\right)$, and pyroligneous extracts concentrations $(0,0.25,0.50,0.75,1.0$, and $2.0 \%)$ on percentage of immobility (PIM) and mortality (PMORT) in Scutellonema bradys. Catolé (a, b) and ouricuri (c, d). Regression equations - PIM: catolé $=23.50+155.1790 * \mathrm{C}-53.443 * \mathrm{C}^{\wedge} 2-0.0323 * \mathrm{~T}\left(\mathrm{R}^{2}=0.937 ; \mathrm{P}<0.05\right)$; ouricuri $=346.33+(176.2720 * \operatorname{Sqrt}(\mathrm{C}))-77.2415 * \mathrm{C}-29.9975 * \operatorname{Sqrt}(\mathrm{T})+0.6491 * \mathrm{~T}\left(\mathrm{R}^{2}=0.974 ; \mathrm{P}<0.05\right)$. PMORT: catolé $=21.84$ $+155.2850 * \mathrm{C}-53.9715 * \mathrm{C}^{\wedge} 2-0.0321 * \mathrm{~T}\left(\mathrm{R}^{2}=0.949 ; \mathrm{P}<0.05\right)$; ouricuri $=460.1630+171.5900 * \operatorname{Sqrt}(\mathrm{C})-(73.2614 * \mathrm{C})-$ 39.8209* $\operatorname{Sqrt}(\mathrm{T})+0.8575 * \mathrm{~T}\left(\mathrm{R}^{2}=0.962 ; \mathrm{P}<0.05\right) . \mathrm{T}=$ temperature; $\mathrm{C}=$ concentration. 


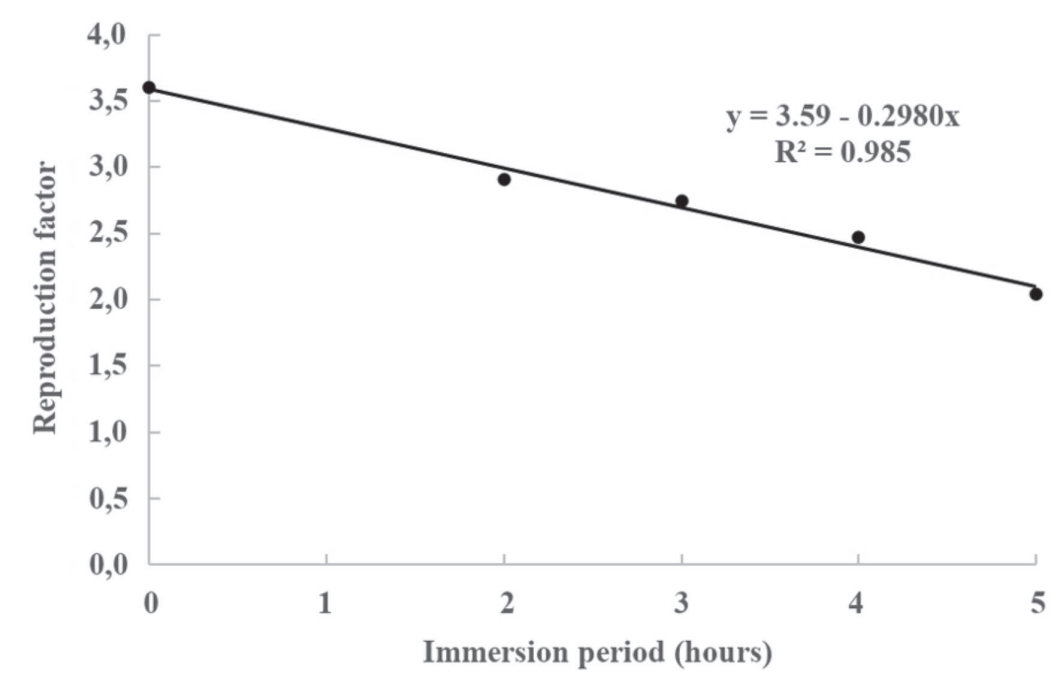

Figure 4: Effect of immersion period (hours) of naturally infected yam tuber seed in coconut pyroligneous extracts at $1 \%$ concentration on reproduction factor of a mixed population formed by Scutellonema bradys and Pratylenchus sp.

plant-parasitic nematodes on yam. However, a RF below 1.0 is desirable to reduce nematode populations in the area (Alves et al., 2011). Then, the pyroligneous extracts of coconut should be investigated in complementary studies, in order to achieve robust results regarding its nematicidal potential.

Studies focused on pyroligneous extracts have shown important bio-activity for other plant-parasitic nematodes, and the efficacy of these products can also occur through indirect action by the plant-induced resistance. The pyroligneous extract Biopirol ${ }^{\circledR}$ (aqueous phase obtained in the distillation of eucaliptus tar), for example, was used as resistance inducer and showed efficacy to reduce the number of eggs and the reproduction factor of M. incognita in tomato (Solanum lycopersicum L.), at the lowest concentration tested $(0.5 \%)$ in all application periods (Melo et al., 2012). In another study, Biopirol ${ }^{\circledR}$ reduced the hatching of second stage juveniles of $M$. incognita, $M$. javanica (Treub) Chitwood, and Tylenchulus semipenetrans Cobb, and also the formation of galls by $M$. incognita and $M$. javanica in tomato roots (Corbani, 2008). The use of Biopirol at 5\% resulted in high suppressive effect on population densities of Pratylenchus and Meloidogyne in sugarcane fields (Rossi \& Lima, 2007). On lettuce (Lactuca sativa L.), efficient nematostatic and nematicidal action of the product against $M$. incognita was observed for all tested concentrations, however, a phytotoxic effect was verified (Santos et al., 2017). Probably, this phytotoxic effect is due to the chemical characteristics of the pyroligneous extract, such as the low $\mathrm{pH}$, that may negatively affect the availability of soil nutrients to the plants. Researchers have pointed out that the application of the pyroligneous extract
PiroQualis ${ }^{\circledast}$ (produced from eucalyptus wood) at $4 \%$ (v/ v) and $8 \%(\mathrm{v} / \mathrm{v})$ induced an increase in the potential acidity, as well as a decrease in $\mathrm{pH}$, base saturation, total cation exchange capacity and calcium concentration in the $0-20 \mathrm{~cm}$ soil layer (Togoro et al., 2014). In the present study, in spite of the acidity ( $\mathrm{pH}$ value of 3.07) of the coconut pyroligneous extract, yam plants did not show symptoms of phytotoxicity.

Despite some information documented in the literature regarding the use of pyroligneous extract against plantparasitic nematodes, positive findings observed for pyroligneous extract obtained from palm trees is now documented for the first time. However, further studies are compulsory in order to evaluate different extract concentrations and immersion periods in the treatment of the yam propagative material infected by the dry rot disease nematodes.

\section{CONCLUSIONS}

Pyroligneous extracts from the palm trees Cocos nucifera, Syagrus cearensis, S. coronata, and Wodetia bifurcata showed nematostatic and nematicidal effect for S. bradys.

Pyroligneous extract from $C$. nucifera reduced the reproduction factor of a mixed population formed by $S$. bradys and Pratylenchus sp. on yam plants.

\section{ACKNOWLEDGEMENTS AND FULL DISCLOSURE}

This study was financed in part by the Coordination for the Improvement of Higher Education Personnel Brazil (CAPES) - Finance Code 001. The authors inform that there is no conflict of interest in carrying the research and publishing this manuscript. 


\section{REFERENCES}

Abdel-Rahman FH, Alaniz N \& Saleh MA (2013) Nematicidal activity of terpenoids. Journal of Environmental Science and Health, 48:16-22.

AGROFIT (2020) Sistemas de Agrotóxicos Fitossanitários. Produtos formulados. Available at: http://agrofit.agricultura.gov.br/ agrofit_cons/principal_agrofit_cons. Accessed on: February $20^{\text {th }}, 2020$.

Almeida TM, Bispo MD, Cardoso ART, Migliorini MV, Schena T, Campos MCV, Machado ME, Loìpez JÁ, Krause LC \& CaramaPo EB (2013) Preliminary studies of bio-oil from fast pyrolysis of coconut fibers. Journal of Agricultural and Food Chemistry, 61:6812-6821.

Alves TCU, Silva RA, Borges DC, Motta LCC \& Kobayast L (2011) Reação de cultivares de soja ao nematoide das lesões radiculares Pratylenchus brachyurus. Revista Biodiversidade, 10:73-79

Aoudia H, Ntalli N, Aissani N, Yahiaoui-Zaidi R \& Caboni P (2012) Nematotoxic phenolic compounds from Melia azedarach against Meloidogyne incognita. Journal of Agricultural and Food Chemistry, 60:11675-11680.

Azevedo FR, Santos CAM, Nere DR, Moura ES \& Gurgel LS (2013) Inseticidas vegetais no controle de Anastrepha spp. (Diptera: Tephritidae) em pomar de goiaba. Holos, 4:77-86.

Basu P (2010) Biomass gasification and pyrolysis: practical design and theory. Burlington, Academic Press. 376p.

Bessa CMAS, Nascimento RS, Alves RCC, Anselmo JM, Silva APSA, Silva AG, Lima VLM, Tavares JF, Silva LCN, Silva MV \& Correia MTS (2016) Syagrus coronata seed oils have antimicrobial action against multidrug-resistant Staphylococcus aureus. Journal of Medicinal Plants Research, 10:310-317.

Booker CJ, Bedmutha R, Vogel T, Gloor A, Xu R, Ferrante L, Yeung KK-C, Scott IM, Conn KL, Berruti F \& Briens C (2010) Experimental investigations into the insecticidal, fungicidal, and bactericidal properties of pyrolysis bio-oil from tobacco leaves using a fluidized bed pilot plant. Industrial \& Engineering Chemistry Research, 49:10074-10079.

Bridgwater AV (2012) Review of fast pyrolysis of biomass and product upgrading. Biomass and Bioenergy, 38:68-94.

Caboni P, Aissani N, Cabras T, Falqui A, Marotta R, Liori B, Ntall N, Sarais G, Sasanelli N \& Tocco G (2013) Potent nematicidal activity of phthalaldehyde, salicylaldehyde, and cinnamic aldehyde against Meloidogyne incognita. Journal of Agricultural and Food Chemistry, 61:1794-803.

Campos AD (2018) Informação técnica sobre extrato pirolenhoso Pelotas, Embrapa Clima Temperado. 9p. (Circular Técnica, 177).

Campos AD (2007) Técnicas para produção de extrato pirolenhoso para uso agrícola. Pelotas, Embrapa Clima Temperado. 8p. (Circular Técnica, 65).

Coimbra JL, Soares ACF, Garrido MS, Sousa CS \& Ribeiro FLB (2006) Toxicidade de extratos vegetais a Scutellonema bradys. Pesquisa Agropecuária Brasileira, 41:1209-1211.

Coolen WA \& D'Herde CJ (1972) A method for the quantitative extraction of nematodes from plant tissue. Ghent, State Agricultural Research Center. 77p.

Corbani RZ (2008) Estudo do extrato pirolenhoso Biopirol® no manejo de nematoides em cana-de-açúcar, olerícolas e citros, em diferentes ambientes. Tese de Doutorado. Universidade Estadual Paulista "Júlio de Mesquita Filho", Jaboticabal. $55 \mathrm{p}$.
Costa CTC, Bevilaqua CML, Morais SM, Camurça-Vasconcelos ALF, Maciel MV, Braga RR \& Oliveira LMB (2010) Anthelmintic activity of Cocos nucifera $\mathrm{L}$. on intestinal nematodes of mice. Research in Veterinary Science, 88:101-103

Czernik S \& Bridgwater AV (2004) Overview of applications of biomass fast pyrolysis oil. Energy \& Fuels, 18:590-598.

Faizi S, Fayyaz S, Bano S, Iqbal EY, Ahmed L, Siddiqi H \& Naz A (2011) Isolation of nematicidal compounds from Tagetes patula L. yellow flowers: structure-activity relationship studies against cyst nematode Heterodera zeae infective stage larvae. Journal of Agricultural and Food Chemistry, 59:9080-9093.

Gao Y, Yang Y, Qin Z \& Sun Y (2016) Factors affecting the yield of bio oil from the pyrolysis of coconut shell. SpringerPlus, $5: 333$.

Guedes CLB, Adão DC, Quessada TP, Borsato D, Galão OF, Mauro ED, Pérez JMM \& Rocha JD (2010) Avaliação de biocombustível derivado do bio-óleo obtido por pirólise rápida de biomassa lignocelulósica como aditivo para gasolina. Química Nova, $33: 781-786$

Hadanu R \& Apituley DAN (2016) Volatile compounds detected in coconut shell liquid smoke through pyrolysis at a fractioning temperature of $350-420{ }^{\circ} \mathrm{C}$. Makara Journal of Science, 20:95100 .

Hughes AFS, Lima FG, Lucchese AM, Neto AG \& Uetanabaro APT (2013) Antimicrobial activity of Syagrus coronata (Martius) Beccari. Brazilian Archives of Biology Technology, 56:269-274.

Igwe OU \& Ugwunnaji IP (2016) Phytochemistry, antioxidant and antimicrobial studies of endosperm tissues of Cocos nucifera L. International Journal of Chemical, Material and Environmental Research, 3:78-83.

Jenkins WRA (1964) A rapid centrifugal-flotation technique for separating nematodes from soil. Plant Disease Reporter, 48:692.

Li G-H, Dang L-Z, Hong L-J, Zheng L-J, Liu F-F, Li L, Liu Y-J \& Zhang K-Q (2009) Nematicidal activity of honokiol and magnolol isolated from Magnolia tripetala. Journal of Phytopathology, 157:390-392.

Lima RS, Muniz MFS, Costa JG, Silva KB, Behling A (2019) Extratos aquosos de Annona spp. e Croton heliotropiifolius sobre Scutellonema bradys e prospecção química dos compostos. Summa Phytopathologica, 45:223-224.

Mai WF \& Mullin PG (1996) Plant-parasitic nematodes: a pictorial key to genera. $5^{\text {th }}$ edition. New York, Cornell University. 288p.

Melo TA, Serra IMRS, Silva GS \& Sousa RMS (2012) Produtos naturais aplicados para manejo de Meloidogyne incognita em tomateiros. Summa Phytopathologica, 38:223-227.

Mohan D, Pittman CU \& Steele PH (2006) Pyrolysis of wood/ biomass for bio-oil: a critical review. Energy \& Fuels, 20:848889.

Moura RM (2016) Doenças do inhame-da-costa (Dioscorea cayennensis). In: Amorim L, Rezende JAM, Bergamin Filho A \& Camargo LEA (Eds). Manual de fitopatologia - doenças das plantas cultivadas. $5^{\text {th }}$ edition. Ouro Fino, Agronômica Ceres. p. 477-483.

Oliveira LMB, Bevilaqua CML, Costa CTC, Macedo ITF, Barros RS, Rodrigues ACM, Camurça-Vasconcelos ALF, Morais SM, Lima YC, Vieira LS \& Navarro AMC (2009) Anthelmintic activity of Cocos nucifera L. against sheep gastrointestinal nematodes. Veterinary Parasitology, 159:55-59.

Pieta S (2017) Eficácia de extratos pirolenhosos de cana-de-açúcar (Saccharum officinarum L.) e eucalipto (Eucalyptus spp.) no controle in vitro de patógenos da soja. Dissertação de Mestrado. Universidade Federal da Grande Dourados, Dourados. 59p. 
Rossi CE \& Lima CB (2007). Controle alternativo de nematoides em cultura orgânica de cana-de-açúcar. Revista Brasileira de Agroecologia, 2:1545-1548.

Santos AM, Almeida FA, Fonseca WL, Leite MLT, Pereira FF \& Carvalho RM (2017) Ácido pirolenhoso no manejo de nematoides das galhas na cultura da alface. Espacios, 38:01-09.

Seo Y \& Kim YH (2014) Control of Meloidogyne incognita using mixtures of organic acids. Plant Pathology Journal, 30:450 455 .

Shaw M (2006) Pyrolysis of lignocellulosic biomass to maximize bio-oil yield: an overview. In: 2006 ASABE Annual Meeting. Edmonton, ASAB. p. 1-14.
Togoro AH, Silva JAS \& Cazetta JO (2014) Chemical changes in an oxisol treated with pyroligneous acid. Ciência e Agrotecnologia, 38:113-121.

Trindade RCP, Palmeira LH, Sant'ana AEG, Sousa RS, Costa APA \& Amorim EPR (2014) Atividade do extrato pirolenhoso sobre lagartas de Spodoptera frugiperda (J.E. Smith) (Lepidoptera: Noctuidae). Revista Brasileira de Agroecologia, 9:84-89.

Vieira WT (2019) Caracterização cromatográfica e avaliação da atividade antimicrobiana do extrato pirolenhoso obtido a partir de biomassas residuais. Dissertação de Mestrado. Universidade Federal de Alagoas, Maceió. 138p. 